\title{
HUBUNGAN DURASI PAPARAN GELOMBANG ELEKTROMAGNETIK TELEPON SELULER TERHADAP KADAR MELATONIN PADA TIKUS PUTIH (Rattus norvegicus) GALUR WISTAR
}

\author{
Irrayanti Putri $^{1}$, Harliansyah ${ }^{2}$ \\ ${ }^{1}$ Fakultas Kedokteran, Universitas YARSI, Jakarta, Indonesia \\ ${ }^{2}$ Fakultas Kedokteran, Universitas YARSI, Jakarta, Indonesia \\ Email: irrayantiputri@gmail.com
}

\begin{abstract}
ABSTRAK
Telepon seluler (ponsel) merupakan alat komunikasi nirkabel yang pada saat ini digunakan oleh masyarakat luas karena memiliki berbagai fitur yang memudahkan pengguna. Ponsel mengeluarkan gelombang elektromagnetik yang menimbulkan berbagai efek negatif terhadap tubuh. Salah satu efek negatif tersebut adalah mengganggu sintesis hormon melatonin yang dapat mengakibatkan irama sirkadian tubuh terganggu. Irama sirkadian tubuh dapat mempengaruhi pola tidur. Islam mengajarkan agar menjaga kesehatan melalui tidur yang teratur pada waktu malam. Mengetahui hubungan durasi paparan gelombang elektromagnetik telepon seluler terhadap kadar melatonin pada tikus putih galur Wistar ditinjau dari kedokteran dan Islam. Penelitian ini adalah eksperimental. Jumlah sampel ditentukan dengan rumus Frederer dan data dianalisis dengan menggunakan IBM SPSS Statistic for Windows. Hasil dari penelitian ini menunjukan kadar melatonin pada kelompok kontrol positif (kontrol gelap) 13,705 \pm 0,500 yang dibandingkan dengan kelompok perlakuan yang diberi paparan selama 3 jam 13,375 $\pm 0,654$ dengan nilai $p$-value $=0,299$ dan selanjutnya jika kontrol positif (kontrol gelap) yang dibandingkan dengan kelompok perlakuan yang diberi paparan selama 6 jam 13,223 \pm 0,529 dengan nilai $p$-value $=0,116$. Tidak terdapat adanya hubungan yang signifikan dari durasi paparan gelombang elektromagnetik telepon seluler terhadap kadar melatonin pada tikus putih (Rattus norvegicus) galur Wistar.
\end{abstract}

Kata Kunci : Gelombang Elektromagnetik, Telepon Seluler, Melatonin, Tikus Wistar

\begin{abstract}
Mobile Phone (MP) is a wireless communication tools that nowadays used by people with many features that can ease the user. Cellphone is releasing electromagnetic radiation that can causes side effect for the user itself, one example of the side effect is disturbing the melatonin hormone synthesis that can cause the abnormal sirkadian body rythm, so the sleep patterns are disrupted, causing insomnia, islam is teaching us to keep our health, for example is to keep the rythm of our bedtime regularly. Knowing the relation between exposure duration of mobile phone electromagnetic radiation to melatonin level of Wistar albino rats observed by medicine and islam perspectives. This study was experimental study, total sample was determined by frederer theory and analyzed using IBM SPSS Statistic 21 for Windows. The results showed that melatonin levels in the positive control group (dark control group) 13,705 $\pm 0,500$ were compared with the group which exposed for 3 hours 13,375 $\pm 0,654$ with $(p=0,299)$ and in the positive control group (dark control group) 13,705 $\pm 0,500$ compared with the group which exposed for 6 hours 13,223 $\pm 0,529$ with $(p=0,116)$. There is no significant relation between exposure duration of mobile phone electromagnetic radiation to melatonin levels in Wistar albino rats. .
\end{abstract}

Keywords : Electromagnetic radiation, Mobile Phone, Melatonin, Wistar Rats 


\section{Pendahuluan}

Telepon seluler (ponsel) adalah salah satu alat komunikasi nirkabel, yang menggunakan gelombang radio sebagai medianya. Keunggulan dari menggunakan gelombang radio jika dibandingkan dengan penggunaan kabel adalah kemampuannya untuk digunakan secara mudah, dapat digunakan di mana saja sepanjang terdapat sinyal di daerah itu. ${ }^{1}$

Ponsel mudah dibawa dan digunakan sehingga saat ini sudah seperti barang yang wajib dibawa oleh sebagian besar masyarakat. Tidak jarang ponsel yang digunakan saat ini adalah ponsel pintar yang memiliki berbagai fitur selain untuk menelepon dan mengirim pesan singkat seperti, kemudahan untuk mengakses internet, penunjuk jalan maupun sebagai perpustakaan buku elektronik.

Banyak pengguna ponsel yang belum mengetahui bahwa ponsel yang digunakan dapat mengirimkan radiasi gelombang elektromagnetik ke dalam tubuh mereka. Sesungguhnya setiap ponsel mempunyai spesifikasi ukuran banyaknya energi gelombang mikro yang dapat menembus ke dalam bagian tubuh seseorang tergantung pada seberapa dekat ponsel dengan kepala. ${ }^{2}$ Gelombang elektromagnetik merupakan gelombang yang terbentuk dari usikan medan magnetik dan medan listrik. $^{3}$ Penelitian menunjukkan bahwa kepala orang dewasa dapat menyerap $80 \%$ dari radiasi yang terpancar dari telepon seluler. ${ }^{4}$

Radiasi yang dipancarkan oleh ponsel dapat mempengaruhi metabolisme serotonin. Serotonin merupakan hormon yang akan disintesis menjadi hormon melatonin. Hormon melatonin disintesis di kelenjar pineal yang terletak di dekat pusat otak. ${ }^{5}$ Metabolisme serotonin yang terganggu akan menyebabkan penurunan produksi melatonin. Penurunan produksi melatonin dapat mengakibatkan gangguan irama sirkadian, penuaan, dan kerentanan terhadap suatu penyakit. ${ }^{6}$ Irama sirkadian merupakan irama siklus fisiologis tubuh yang berulang setiap 24 jam mengikuti perputaran siang dan malam yang teratur. ${ }^{7}$ Selain itu radiasi ponsel juga memberikan dampak ringan maupun berat kepada penggunanya. Salah satu dampak berat yang diakibatkan oleh radiasi adalah insomnia. Insomnia adalah persepsi tentang kurangnya kualitas dan kuantitas tidur yang diakibatkan oleh gangguan irama sirkadian. Sehingga dapat dikatakan bahwa penurunan produksi melatonin dapat menyebabkan insomnia. ${ }^{6}$

\section{Metode Penelitian}

Jenis penelitian yang dilakukan adalah jenis penelitian eksperimental. Tujuan penelitian ini yaitu untuk mengetahui bagaimana hubungan durasi paparan gelombang elektromagnetik telepon seluler terhadap kadar melatonin pada tikus putih (Rattus norvegicus) galur Wistar. Rancangan penelitian yang Penelitian menggunakan rancangan penelitian Post Test Only Control Group Design yaitu dengan cara membandingkan hasil observasi pada kelompok kontrol dan perlakuan. Data-data yang dapat menunjang terlaksananya penelitian ini diperoleh dengan menetapkan jumlah populasi yang digunakan dihitung dengan rumus Frederer.

Sampel penelitian adalah tikus putih (Rattus norvegicus) galur Wistar, berusia 3-4 bulan dengan berat badan awal sekitar 130-150 g.

Cara penetapan sampel adalah dengan simple random sampling. Populasi dinggap homogen dan bisa diambil sampelnya secara acak.

Penelitian ini menggunakan data kuantitatif yang kemudian dimasukkan ke dalam tabel data. Analisis data menggunakan Uji Mann-Whitney.

\section{Hasil}

Data pada penelitian ini diambil menggunakan metode simple random sampling dengan jumlah sampel 24 ekor tikus. Pada penelitian ini dilakukan pengujian dan analisis untuk menentukan panjang gelombang maksimal dan kurva standar dari melatonin standar.

Hasil pengujian dapat dilihat pada Gambar 4.1 untuk melihat panjang gelombang maksimal dan kurva standar dari melatonin standar yang menunjukkan bahwa panjang 
gelombang maksimal dari melatonin standar adalah $280 \mathrm{~nm}$ karena absorbansi tertinggi dari larutan standar terdapat pada gelombang $280 \mathrm{~nm}$. Dari hasil perhitungan persamaan regresi yang didapat adalah $y=0,003 x-0,076$.

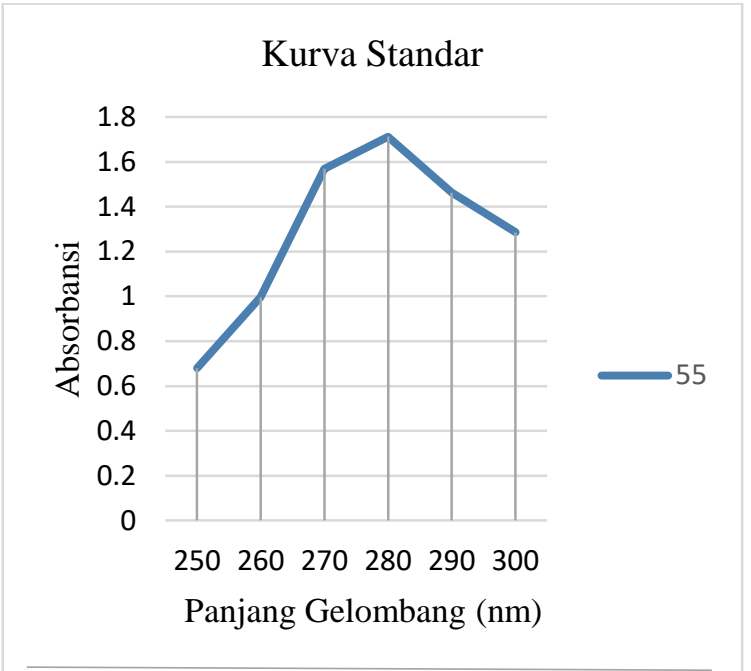

\section{Gambar 4.1. Kurva Standar Melatonin}

Sampel yang digunakan sebanyak 6 sampel dalam setiap kelompok. Hasil absorbansi dari setiap sampel kemudian dimasukkan persamaan regresi yang didapat dari hasil perhitungan melatonin standar utnuk mendapatkan nilai kadar melatonin pada serum darah sampel yang terdapat pada Gambar 4.2.

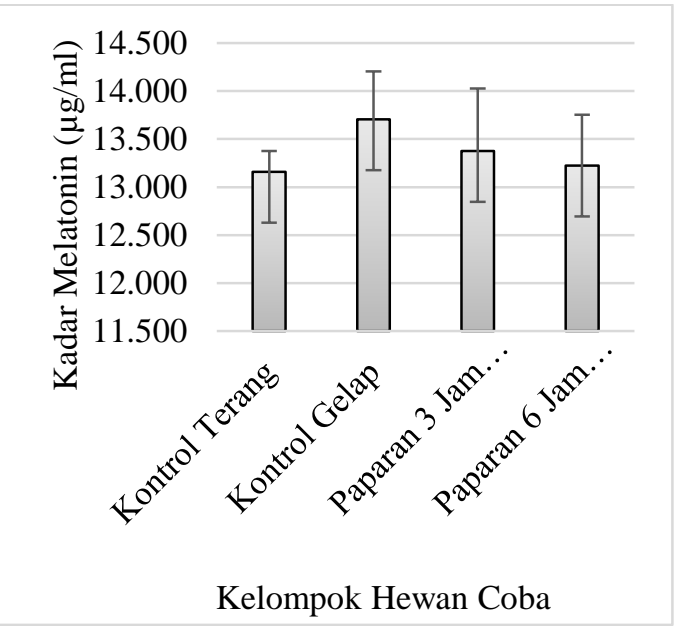

\section{Gambar 4.2. Diagram Kadar Melatonin pada Serum Darah Sampel}

Selanjutnya dilakukan uji normalitas yang dibuat dengan grafik Normal P-P plot of regression standardized residual. Terdapat pada Gambar 4.3.

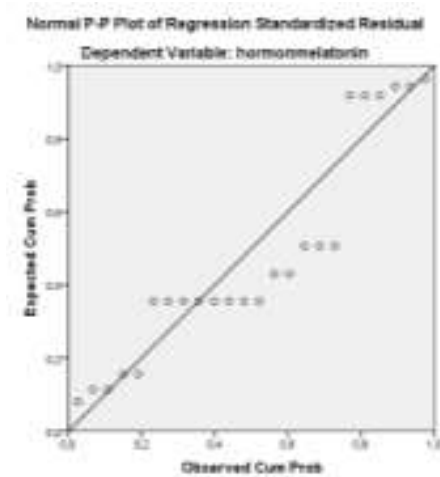

Gambar 4.3. Normal P-P plot of regression standardized residual

Pada Gambar 4.3. bahwa sebaran data pada grafik tersebut tidak tersebar pada sekeliling garis lurus sehingga normalitas tidak terpenuhi. Uji normalitas tidak terpenuhi karena sebaran data yang tidak normal, maka dilakukan pengujian statistik lainnya yaitu uji Mann-Whitney.

Tabel 4.1. Kadar Melatonin Pada Serum Darah Sampel

\begin{tabular}{|c|c|c|c|}
\hline Kelompok & Mean \pm SD & $\begin{array}{c}p- \\
\text { value }\end{array}$ & $\mathbf{N}$ \\
\hline $\begin{array}{c}\text { Kontrol } \\
\text { Gelap }\end{array}$ & $\begin{array}{c}13,705 \pm \\
0,500\end{array}$ & - & 6 \\
\hline $\begin{array}{c}\text { Paparan } 3 \\
\text { Jam Suasana } \\
\text { Gelap }\end{array}$ & $\begin{array}{c}13,375 \pm \\
0,654\end{array}$ & 0,299 & 6 \\
\hline $\begin{array}{c}\text { Paparan } 6 \\
\text { Jam } \\
\text { Suasana } \\
\text { Gelap }\end{array}$ & $\begin{array}{c}13,223 \pm \\
0,529\end{array}$ & 0,116 & 6 \\
\hline
\end{tabular}

Hasil Uji Mann-Whitney Tabel 4.1 yang dilakukan pada kelompok kontrol negatif (kelompok kontrol terang) 13,160 $\pm 0,218$ dengan kelompok kontrol positif (kelompok kontrol gelap) 13,705 $\pm 0,500$ menunjukan nilai $p$-value $=0,043(\mathrm{p}<0,05)$. Pada kelompok kontrol positif (kelompok kontrol gelap) $13,705 \pm 0,500$ dengan kelompok perlakuan yang diberi paparan selama 3 jam dalam suasana gelap 13,375 $\pm 0,654$ menunjukan nilai $p$-value $=0,299(\mathrm{p}>0,05)$. Pada kelompok kontrol positif (kelompok kontrol gelap) 
13,705 $\pm 0,500$ dengan kelompok perlakuan yang diberi paparan selama 6 jam dalam suasana gelap 13,223 $\pm 0,529$ menunjukan nilai $p$-value $=0,116(\mathrm{p}>0,05)$.

\section{Pembahasan}

Telepon seluler (ponsel) atau telepon nirkabel sekarang menggantikan telepon kabel sehingga dapat digunakan dimana saja di kehidupan kita. Peningkatan penggunaan ponsel menimbulkan kekhawatiran tentang risiko terkait kesehatan yang mempengaruhi kualitas hidup. Saat ini, ponsel generasi ketiga (3G) lebih sering digunakan. Tidak diragukan lagi, aplikasi ponsel 3G, seperti panggilan berbasis video, pesan, dan sebagainya, memancarkan radiasi elektromagnetik ke lingkungan. ${ }^{8}$ Perangkat elektronik, seperti ponsel, pesawat televisi atau pemancar radio, memancarkan radiasi elektromagnetik dengan frekuensi tinggi dari $300 \mathrm{MHz}$ sampai 300 GHz. $^{9}$

Paparan gelombang elektromagnetik ponsel dapat mengganggu sintesis hormon melatonin. Melatonin memainkan peran penting dalam mengendalikan banyak proses fisiologis yang terjadi dalam ritme harian, seperti tidur, metabolisme, dan reproduksi. Selain itu, melatonin juga terlibat dalam regulasi irama sirkadian, sistem kekebalan tubuh, dan sistem kardiovaskular. ${ }^{9}$ Irama sirkadian mengacu pada proses biologis yang berosilasi dengan periode yang sama dengan 24 jam. ${ }^{10}$

Hasil uji Mann-Whitney menunjukan adanya hubungan korelasi yang signifikan antara kadar hormon melatonin pada kelompok kontrol terang dengan kadar hormon melatonin pada kelompok kontrol gelap dengan $p$-value $0,043(<0,05)$. Hubungan korelasi antara kelompok kontrol gelap dengan kelompok perlakuan yang diberi paparan gelombang elektromagnetik telepon seluler selama 3 jam dan 6 jam dari hasil uji Mann-Whitney menunjukan hasil yang tidak signifikan dengan p-value $>0,05$.

Secara statistik tidak didapatkan adanya hubungan antara lamanya paparan gelombang elektromagnetik ponsel dengan penurunan hormon melatonin pada hewan uji, namun jika dilihat pada gambar 4.2 terlihat adanya pola penurunan pada hormon melatonin dengan lamanya paparan. Perbedaan fenomena tersebut kemungkinan disebabkan karena jumlah hewan uji yang sedikit. Penelitian Halgamuge (2013) menunjukkan hasil kadar melatonin pada malam hari atau suasana gelap ternyata tidak berubah akibat pancaran radiasi gelombang elektromagnetik ponsel, namun bisa menimbulkan efek pada waktu pembuatan atau sintesis hormon melatonin. ${ }^{11}$

\section{Simpulan}

Berdasarkan hasil penelitian diperoleh kesimpulan tidak adanya hubungan durasi papaparan gelombang elektromagnetik telepon seluler terhadap kadar hormon melatonin pada tikus putih (Rattus norvegicus) galur Wistar.

\section{Saran}

Dari hasil penelitian ini dapat disarankan untu memperpanjang waktu pemberian perlakuan pada hewan uji, membuat pengulangan sampel yang lebih banyak atau memiliki jumlah sampel yang lebih banyak, memperhatikan lingkungan sekitar lokasi penelitian (kandang, suasana gelap atau terang, suhu dan kelembapan ruangan, dan lain-lain), memperhatikan ada atau tidak sumber paparan gelombang elektromagnetik selain dari telepon seluler yang digunakan untuk penelitian, serta lebih teliti dalam pengolahan sampel atau data.

\section{Daftar Pustaka}

1. Idayati, R. Pengaruh Radiasi Handphone Terhadap Kesehatan. Jurnal Kedokteran Syiah Kuala. 2011; 11(2): 115-120.

2. Swamardika, I. A. Pengaruh Radiasi Gelombang Elektromagnetik. Teknologi Elektro. 2009; 8: 106-109.

3. Mahardika, I. d. Efek Radiasi Elektromagnetik Ponsel Terhadap Kesehatan Manusia. 2008.

4. Battung, R. O., Rumampuk, J. F. \& Supit, W. Hubungan Radiasi Gelombang Elektromagnetik Telepon Seluler Terhadap Fungsi Pendengaran Mahasiswa Angkatan 2009 Fakultas Kedokteran Universitas Sam Ratulangi Manado. Jurnal e-Biomedik. 2013; 1: 1047-1052. 
5. Cherry, N. EMF/EMR Reduces Melatonin in Animals and People. Canterbury: Human Sciences Department Lincoln University. 2002.

6. Enny. Efek Samping Penggunaan Ponsel. Gema Teknologi. 2014; 17: 178-183.

7. Agustin, D. Faktor-Faktor yang Mempengaruhi Kualitas Tidur pada Pekerja Shift di PT Krakatau Tirta Industri Cilegon. Skripsi. Fakultas Ilmu Keperawatan Universitas Indonesia, Depok. 2012.

8. Colak, C. et al. Effects of electromagnetic radiation from $3 \mathrm{G}$ mobile phone on heart rate, blood pressure and ECG parameters in rats. Toxicology and Industrial Health. 2012; 28(7): 629-638.

9. Lewczuk, B. et al. Influence of Electric, Magnetic, and Electromagnetic Fields on the Circadian System: Current Stage of Knowledge. BioMed Research International. 2014; 1-13.

10. Kovacic, P. and Somanathan, R. Cell signaling, receptors, electrical effects and therapy in circadian rhythm. Journal of Receptors and Signal Transduction. 2013; 33(5): 267-275.

11. Halgamuge, M. N. Pineal melatonin level disruption in humans due to electromagnetic fields and ICNIRP limits. Radiation Protection Dosimetry. 2013; 154(4): 405-416. 
ISSN 0216-3438 (print). ISSN 2621-1122 (online) | Jurnal Profesi Medika | Vol. 12, No. 1. 2018 